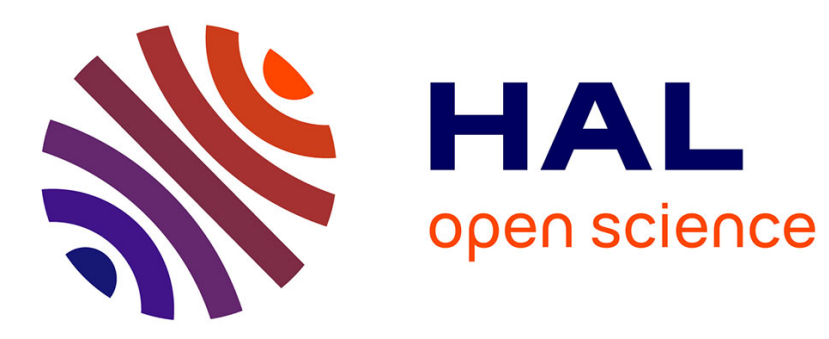

\title{
Manufacturing antibodies in the plant cell
}

Diego Orzáez, Antonio Granell, Miguel A. Blázquez

\section{To cite this version:}

Diego Orzáez, Antonio Granell, Miguel A. Blázquez. Manufacturing antibodies in the plant cell. Biotechnology Journal, 2009, 4 (12), pp.1712. 10.1002/biot.200900223 . hal-00546226

\section{HAL Id: hal-00546226 https://hal.science/hal-00546226}

Submitted on 14 Dec 2010

HAL is a multi-disciplinary open access archive for the deposit and dissemination of scientific research documents, whether they are published or not. The documents may come from teaching and research institutions in France or abroad, or from public or private research centers.
L'archive ouverte pluridisciplinaire HAL, est destinée au dépôt et à la diffusion de documents scientifiques de niveau recherche, publiés ou non, émanant des établissements d'enseignement et de recherche français ou étrangers, des laboratoires publics ou privés. 


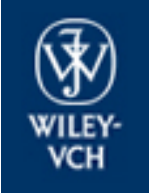

Biotechnology Journal

\section{Manufacturing antibodies in the plant cell}

\begin{tabular}{|r|l|}
\hline Journal: & Biotechnology Journal \\
\hline Manuscript ID: & biot.200900223.R1 \\
\hline Wiley - Manuscript type: & Review \\
\hline Author: & $24-$ Oct-2009 \\
\hline Complete List of Authors: & $\begin{array}{l}\text { Orzáez, Diego; Instituto de Biología Molecular y Celular de Plantas } \\
\text { (CSIC-UPV) } \\
\text { Granell, Antonio; Instituto de Biología Molecular y Celular de } \\
\text { Plantas (CSIC-UPV) } \\
\text { Blázquez, Miguel; Universidad Politecnica de Valencia, Instituto de } \\
\text { Biologia Molecular y Celular de Plantas (UPV-CSIC) }\end{array}$ \\
\hline Keywords: & $\begin{array}{l}\text { Molecular farming, Plant-made antibodies, Plantibodies, sIgA, } \\
\text { Agroinfiltration }\end{array}$ \\
\hline
\end{tabular}

\section{s ScholarONE \\ Manuscript Central}


Review ((9361 words))

. Manufacturing antibodies in the plant cell

Diego Orzáez, Antonio Granell and Miguel A. Blázquez

Instituto de Biología Molecular y Celular de Plantas (CSIC-UPV), Valencia, Spain.

\section{Keywords:}

Molecular farming; Plant-made antibodies; Plantibodies; Glycosylation; Viral vectors;

Agroinfiltration; sIgA; Unfolded Protein Response.

\section{Correspondence:}

Diego Orzáez

Instituto de Biología Molecular y Celular de Plantas (CSIC-UPV)

Ingeniero Fausto Elio s/n

46022 Valencia

Spain

Phone, +34 963877873

Fax, +34 963877859

E-mail,dorzaez@ibmcp.upv.es
Deleted: Title :

Deleted: and
Deleted: 46021

Deleted: $x x x$ 


\begin{abstract}
Abbreviations:
BiP, Immunoglobulin Heavy Chain Binding Protein; CHO, Chinese Hamster Ovary;

CDR, Complementarity-Determining Regions; ER, Endoplasmic Reticulum; UPR,

Unfolded Protein Response; ERAD, Endoplasmic Reticulum Associated Protein

Degradation; TMV, Tobacco Mosaic Virus; TSP, Total Soluble Protein;
\end{abstract}

Deleted: 
Deleted: as

Plants have long been considered advantageous platforms for large-scale production of antibodies due to their low cost, scalability, and the low chances of pathogen contamination. Much effort has therefore been devoted to efficiently produce mAbs (from nanobodies to secretory antibodies) in plant cells. Several technical difficulties have been encountered and are being coped with. Improvements in production levels have been achieved by manipulation of gene expression and, more efficiently, of cell targeting and protein folding and assembly. Differences in $\mathrm{mAb}$ glycosylation patterns between animal and plant cells are being successfully addressed by the elimination and introduction of the appropriate enzyme activities in plant cells. Another relevant battlefield is the dichotomy between production capacity and speed. Classically, stably transformed plant lines have been proposed for large scale $\mathrm{mAb}$ production, whereas the use of transient expression systems has always provided production speed at the cost of scalability. However, recent advances in transient expression techniques have brought impressive yield improvements, turning speed and scalability highly compatible assets. In the era of personalized medicines, the combination of yield and speed, and the advances in glyco-engineering have made the plant cell a serious contender in the field of recombinant antibody production. 


\section{Introduction}

Recombinant gene technology is called to be one of the main ways to respond to the increasing manufacturing needs for novel molecular entities. Since the production of human insulin in E. coli, more than one hundred recombinant therapeutic drugs have been approved for commercialization and a tremendous amount of recombinant proteins are being used in diagnosis or research [1]. Fermentation in prokaryotes and yeast accounts for the majority of recombinant products; however, the increasing complexity of products is promoting the use of eukaryotes other than yeast as production systems. Such is the case of Chinese Hamster Ovary (CHO) cells, baculovirus-infected insect cells, and transgenic/transplactomic plants or plant cells. All these platforms have dramatically improved their performance in recent years to cope with to the expected shortage of recombinant protein manufacturing capacity $[2,3]$, For instance, the modifications introduced in prokaryotic systems have made them increasingly able to produce and display complex proteins $[4]$ or have facilitated the introduction of whole metabolic pathways [5]; similarly, yeast strains have been engineered to display nearlyhuman glycosylation profiles $[6]$; $\mathrm{CHO}$ cells have multiplied their yields, reaching $\mathrm{g} / \mathrm{L}$ levels [7]; alternative animal systems as chicken eggs have arisen [8], and baculovirusbased systems have been adapted to the production of multi-subunit protein complexes [9l,

Monoclonal antibodies (mAbs) have attracted much of the effort in the field of recombinant protein technology. mAbs combine two types of bioactivities in the same molecule: the high binding specificity of their variable region, and the well-defined structure and effector functions of their constant regions. In addition, bioengineers have taken full advantage of this "natural" structure for the design of an array of antibody-

Field Code Changed

Deleted: the
Deleted: synthesized
Deleted: other

Deleted: , adapting

Field Code Changed

Deleted: [2]

Field Code Changed

Deleted: [3]

Field Code Changed

Deleted: [4]

Deleted: improved

Deleted: strains

Deleted: ing

Deleted: have been designed

Field Code Changed

Deleted: [5]

Field Code Changed

Deleted: [6]

Field Code Changed

Deleted: [7]

Field Code Changed

Deleted: [8]

Deleted: MAb

Deleted: $s$

Deleted: MAbs

Deleted: $s$ 
related structures. As a consequence, recombinant antibodies and their manmade derivatives have become a sort of magic bullet of modern biotechnology [10]. They are widely used as diagnostic reagents, both in health and research, but also more recently as therapeutic drugs, particularly for cancer treatments, where they have shown high efficacy $₫ 11\rceil$

Human recombinant $m$ Abs have entered the anti-tumor therapy mainstream through several technological waves. Initially, when just murine hybridoma technology was available the only $m A$ bs were of mice origin. Therapeutic antibodies were then "humanized" by grafting the murine regions into human $\operatorname{IgG}$ constant frames. "Humanization" of murine mAbs was further improved by exchanging mouse scaffolds in the Complementarity-Determining Regions (CDR) for sequences of human origin. Finally, when phage display technology was developed for the screening of antibodybinding regions, human antibody libraries became available that allowed reconstitution of fully-human recombinant antibodies for therapy $[11,12 \downarrow$

Manufacturing technology was developing in parallel with display technologies. Initially there was not a definitive platform for the production of recombinant antibodies. Unlike single chain ( $\mathrm{scFv}$ ) antibody fragments, which could be produced as periplasmic proteins in bacterial fermentors, the more complex full-size recombinant antibodies required eukaryotic cells as biofactories. Plants, among others, were postulated from the beginning as a suitable production platform [13] Transgenic plants' technology was however too slow and rudimentary to compete, and CHO cells finally became the standard for the antibody industry. To this date, all commercial therapeutic antibodies are produced in $\mathrm{CHO}$ cell fermentors. However monopoly of $\mathrm{CHO}$ cells is likely bound to end in the next few years, as laboratories and private companies demand new capabilities, such as speed, scalability and freedom to operate. 


\section{Different formats for different purposes: from nanobodies to secretory $\operatorname{IgA}$}

Recombinant antibody-based molecular designs range from those most faithfully imitating nature, as $\operatorname{IgG}$, to those aimed at maximum simplicity, as nanobodies, or those more complex or innovative designs, as immune-complexes or multivalent structures. Each design, having its particular biosynthetic requirements (i.e. folding, secretion, glycosylation), may suit for certain production platforms and not others. Here we review those antibody formats that have been produced in plants and their adequacy to the plant production systems.

\subsection{Full size antibodies}

Human IgG (Fig. 1) is probably the most wanted mAb isotype for plant production, because of its widespread use as an anti-tumor agent. In addition, downstream purification methods for IgG are well established and protein A affinity purification is a recognized safe standard for posterior therapeutic applications. Full size antibodies in 
stably transformed plants are normally produced using dual gene constructs encoding the heavy $(\mathrm{H})$ and light $(\mathrm{L})$ chains each of them under the control of a promoter and a transcriptional terminator. Human immunoglobulin native signal peptides are well recognized in the plant cell, although certain authors prefer the use of plant native signal peptides $[18]$ Both expression cassettes are often combined within the same binary vector frame (also referred to as "co-transformation in cis"). The goal is to provide coordinated expression of both antibody chains, which has been often considered a prerequisite for stable IgG expression $[19 l$, These complex constructs are often difficult to engineer, extending the antibody development process. Alternative methods are "sequential co-transformation", using different selection markers, and "cotransformation in trans", with $\mathrm{H}$ and $\mathrm{L}$ chains (and any additional polypeptide) inserted in different expression cassettes and transformed simultaneously using a single selection marker. This latter approach has been reported for cereals in combination with biolistics [20孔 yielding high levels of co-transformation. The use of biolistics facilitates construct manipulation due to the elimination of the requirement for large binary vectors used in Agrobacterium-based transformation. In consequence, the development phase for recombinant $\mathrm{mAb}$ production is accelerated. Nevertheless, form the pionner work of Hiatt et al [13] to the most recent production of anti-HIV prophylactic IgG in corn [21, 22l, the lengthy process of establishing a homozygous transgenic plant line with stable and homogeneous IgG production has been the Achilles' heel of plant-made antibodies. More recently, the use of transient expression systems has contributed to ease these limitations, paying a toll in scalability. The use of transient expression systems for IgG production will be discussed in the section below.

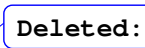

Deleted: chapter

\subsection{Antibody fragments}


The observation that $\mathrm{H}$ chains retain some antigen-binding capacity even in the absence of $\mathrm{L}$ chains led to attempts to develop an even smaller antigen-binding unit in a miniaturized format. The smallest format found to keep full binding activity was the socalled single-chain fragment ( $\mathrm{scFv}$ ), in which the two variable regions, VH and VL, are artificially linked by a flexible polypeptide (Fig. 1) There are several examples in the literature showing $\mathrm{scFv}$ expression in different plant species (tobacco, tomato, pea) and plant organs (leaves, fruits, seeds) $[14 \downarrow$ The reported production levels are also highly variable: in general scFvs are better expressed as ER-retained proteins, from almost undetectable levels to up to $6 \%$ TSP $[23]$

By serendipity, it was discovered that part of the humoral immune response of camels and llamas is based largely on H-chain antibodies where the $\mathrm{L}$ chain is missing. These unique antibody isotypes interact with the antigen through a single variable domain, referred to as VHH [24L(Fig. 1). Single domain antibodies have been produced in plants for immunomodulation of enzyme activity [25] Plants may also be used as production platforms of single domain antibodies, although in certain circumstances VHHs may result toxic when produced in leaves at high levels (Orzaez et al, unpublished results).

It has to be kept in mind that $\mathrm{scFv}$ and $\mathrm{VHH}$ do not require glycosylation and can be assembled in prokaryotic systems like $E$. coli fermentors, which constitute therefore a strong competitor for plants. For the same reason, transplastomic plants are also suitable for the production of recombinant antibody fragments $[17 \downarrow$

In the production of miniaturized antibodies, plants offer selective advantages compared to other platforms: the almost unlimited scaling up capacity and their use for food and animal feed makes plants an ideal platform for the development of veterinary vaccines_[26, This was the case for the pea seed production platform for anti-

Field Code Changed

Deleted: [14]

Deleted: a

\begin{tabular}{l} 
Deleted: against \\
Deleted: ir \\
\hline Deleted: , which \\
Deleted: made \\
Deleted: them \\
Field Code Changed \\
Deleted: [26]
\end{tabular}

Deleted: The observation that $\mathrm{H}$ chains retain some antigen-binding capacity in the absence of $L$ chains led to attempts to obtain an even smaller antigen-binding unit in a $\mathrm{VH}$ format (Figure 1). However, several engineering efforts had to be made to overcome the reduced affinity for the antigen. As a result, scFvs were generated, in which the two variable regions, VH and VL, are artificially linked by a flexible polypeptide (Fig. $1)$.

Field Code Changed

Deleted: [11]

Field Code Changed

Deleted: [23]

Field Code Changed

Deleted: [24]

Field Code Changed

Deleted: [25] 
coccidiosis antibody fragments once pursued by german-based company NovoPlant as a prophylactic device agent against chicken coccidiosis_[27, 28] This and similar approaches may still be considered as highly convenient once the negative European public perception on biofarming eases its halt in the development of local companies specialized in antibody production.

\subsection{Innovative antibody-based structures}

A number of plant-made antibody-based structures has been proposed for improving stability, downstream processing or immune functions. Taking advantage of the stability conferred by IgG constant regions during expression in plants, chimeric molecules containing an antigenic (HIV-1 p24) region fused to $\mathrm{C} \gamma 1-2$ regions of $\mathrm{IgG} \mathrm{H}$ chain have been shown to stabilize antigen production [29], In another example, antibody fusion with elastin like proteins was shown to increase anti-HIV $\mathrm{mAb}$ yields and to facilitate downstream processing, without affecting neither their properties nor their glycosylation patterns $[30,31\rceil$, Particularly challenging structures for plant expression are recombinant immune complexes $[32]$, which consist of complex arrangements where a certain antibody is fused against its own antigen creating a structure with potential immunomodulating activity. It is foreseeable that, as we learn more about immunological concepts like adjuvancy, immunomodulation and tolerance, newly designed antibody-based molecular structures with improved biological activity are likely to appear that will require a suitable platform (i.e plants) for large scale production.

\subsection{Secretory antibodies}

Deleted:

Deleted: for

\begin{tabular}{l|}
\hline Field Code Changed \\
\hline Deleted: [28] \\
\hline Deleted: 2F5 \\
\hline Deleted: MAb \\
\hline Deleted: neither its \\
\hline Deleted: biochemical \\
\hline Deleted: its \\
\hline Field Code Changed \\
\hline Deleted: [29] \\
\hline Field Code Changed \\
\hline Deleted: [30] \\
\hline Deleted: in \\
\hline Deleted: on \\
\hline
\end{tabular}


A particularly interesting antibody isotype for plant-base production is the secretory immunoglobulin A (sIgA). In mammals, $\operatorname{sIg} \mathrm{A}$ is the most important antibody isotype for mucosal protection. SIgA is formed in two stages (Fig. 2): First, B-lymphocytes produce dimeric IgA molecules in the lamina propria. Dimerization is regulated by the J-chain. Later, IgA dimers ( $\mathrm{dIgAs}$ ) bind to the polymeric immunoglobulin receptor (pIgR) at the basolateral surface of mucosal epithelium cells and are subsequently transcytosed to the intestinal lumen. Here the extracellular portion of pIgR, known as secretory component (SC), is proteolytically cleaved and remains attached to the $\operatorname{IgA}$ polymer rendering the heteromultimeric structure known as $\operatorname{IgA}$, This antibody isotype constitutes a highly stable complex that covers mucosal surfaces, acting as a first barrier against infection $[33$ ㄴ

Bulk production of $\operatorname{sIg} \mathrm{A}$ for passive immunotherapy requires efficient, low cost manufacturing systems. Ma and co-workers demonstrated that plant cells can assemble mammalian antibodies in a secretory form: tobacco plants transformed with all four genes encoding chimeric sIgA/G produced fully functional secretory antibodies $[34$, The secretory version of this antibody accumulated at high levels in the plant, retained specificity against Streptococcus mutans, and conferred protection against dental caries [35] In fact, a milestone for plant molecular farming was the first EU approval for the commercialization of a plant-made recombinant product, which was awarded to California based company Planet-Biotech for the production of sIgG/A as a medical device for human health. Human SIgA has also been assembled in rice and corn endosperm $[20,36\rceil$ and recombinant bird sIgA complexes against Eimera have been transiently assembled in tobacco plants [37], SIgA has a great potential as a prophylactic molecule for the protection against pathogens that infect mucosal surfaces. In this sense, Deleted: ecretory Deleted: . Secretory IgA (sI Deleted: gA) Field Code Changed Deleted: [31] Field Code Changed Deleted: [32] Field Code Changed Deleted: [33] Deleted: that

Deleted: also Field Code Changed Deleted: [20,34] Field Code Changed Deleted: [35] Deleted: SIgA 
in large amounts as required for passive prophylactic agents; moreover, partially purified, mucosal compatible plant-derived formulations containing sIgA could become an affordable vehicle for treatment and/or prevention of infection in oral or topical routes $[381$

\section{Potential molecular targets for the activation of antibody production in the plant cell}

How to make a plant cell resemble a lymphocyte in terms of antibody production is a challenging biotechnology work. A close look at how mAbs are made in natural mAb biofactories, the mammalian plasma cells, can give clues on how to improve current technology in plants.

Lymphocytes differentiate into plasma cells upon co-activation by antigen and helper T-cells. The hallmarks of this differentiation are a cell division arrest, size increase and the expansion of the endomembrane system that ensures high levels of protein secretion. In agreement with the expansion of the secretion machinery, differentiating plasma cells up-regulate their levels of ER chaperones and other ERresident enzymes as $\mathrm{BiP}$ and Disulfide Isomerase. This phenomenon resembles the Unfolded Protein Response (UPR), a conserved mechanism activated in response to ER stress \39] In the current model for UPR, three proteins act as proximal transducers: the Inositol-Requiring Enzyme 1 (IRE1), the Activating Transcription Factor 6 (ATF6) and the Protein kinase-like Endoplasmic Reticulum Kinase (PERK). All three elements are expressed constitutively and bound to BiP in basal conditions. Their release from BiP, either due to stress or as a response of a developmental program, unleashes a transcriptional response mediated by the X-box Binding Protein 1 (XBP1) transcription
Deleted: the

Deleted: as

Deleted: the

Field Code Changed

Deleted: [36]

Deleted: Inspired by nature:

mammalian cells producing antibodies

Deleted: MAb

Deleted: lymphocytes and

Deleted: In their natural

biofactories, the lymphocytes,

antibodies are synthesized through

the cell endomembrane system.

Antibody synthesis requires

coordinated expression, folding and assembly of $\mathrm{H}$ and $\mathrm{L}$ chains. First, the corresponding mRNAs are

matured and translated in the rough ER; then their nascent polypeptides are translocated into the ER and the

$\mathrm{N}$-terminal signal peptide is

subsequently cleaved; folding is assisted by ER resident chaperones as the Immunoglobulin Heavy Chain Binding Protein (BiP) [37]. Besides, the Endoplasmic Reticulum

Associated Protein Degradation

(ERAD) quality control mechanism ensures that unfolded antibody chains are removed from the ER and degraded via the proteosome [38]. Finally, antibody chains are linked together by disulfide bonds

established by ER-resident protein disulfide isomerase (PDI) [39]. II

In artificial systems such as $\mathrm{CHO}$

cells, several genetic strategies have been followed to increase MAb

production. This includes engineering of anti-apoptotic factors to inhibit cell death in high density

cultures, an approach that can be

directly translated to plant cell suspension systems but possibly not to transgenic plants. A second obvious strategy consists in increasing gene expression by different means, like raising recombinant gene copy number, using more active promoters or targeting recombinant DNA to active transcriptional sites. These approaches, which do have a clear parallel in plants, have been only partially successful. It is generally accepted that MAb yield is not

always a reflection of the abun

Deleted: 1

Field Code Changed

Deleted: [41] 
factor that results in the activation of several chaperones, but also apoptosis if certain injury threshold is reached $[401$.

The understanding of the molecular mechanisms for plasma cell differentiation has opened the way for the rational engineering of artificial cells through the genetic upregulation of a complete pathway instead of discrete genes. This was recently accomplished by overexpression of truncated version of XBP1 in $\mathrm{CHO}$ cells, which successfully induced a constitutive UPR that turned out in a significant increase in $\mathrm{mAb}$ production $[41]$

Is there a lesson to be learned from plasma cell differentiation in plant-made antibodies? Could plant mAb production be enhanced by activation of UPR? A closer look at the way the plant cell endomembrane system copes with an increase in the demands for protein secretion could give some clues on how this could be accomplished.

There are at least two circumstances in which plant cells activate their endomembrane system in a way that resembles plasma cell differentiation: during seed development and in response to pathogen attack. In both situations plant cells activate a developmental program that is equivalent to the yeast and mammalian UPR, and can be experimentally induced by the treatment with ER-stress inducers such as tunicamycin, an inhibitor of $\mathrm{N}$-glycosylation $[42,43]$

During the establishment of Systemic Acquired Resistance (SAR) in response to pathogen attack, Pathogenesis Response (PR) proteins are produced and sent to the vacuole and apoplast in high amounts. NPR1, a well-known master regulator of SAR, has also been shown to control the expression of protein secretory pathway genes [44] unveiling an interesting link between SAR and plant UPR. Indeed a certain parallelism can be drawn between lymphocyte activation in the vertebrate immune system and the
Deleted: MAb

Field Code Changed

Deleted: [43]

Deleted: II

Deleted: 4 Potential molecular targets for the activation of secretory pathway in the plant cell 1 Deleted: MAb

Deleted: to

Deleted: that
Deleted: glycosilation Field Code Changed Deleted: [44, 45] Deleted: a 
activation of SAR in the plant immune system: in vertebrates, the presence of non-self peptides or pathogen antigens indirectly activates, with the concurrence of T-helper cells and cytokines, the differentiation of plasma cells and/or the activation of cytotoxic $\mathrm{T}$ cells, natural secretory factories of antibodies. In a similar fashion, plant cells which are distant from the site of infection undergo the activation of a defense response by diffusible compounds like salicylic acid,

Once the link between UPR and SAR is established, it is interesting to look for plant regulators of UPR as potential candidates for activating the secretory pathway in plants. IRE1 homologues have been identified in plants; however their involvement in plant UPR has not been established. Although plants lack clear orthologues of XBP1 or ATF6, the promoters of ER chaperones, such as BiP, do contain regulatory elements responsible for ER-stress response. In Arabidopsis, at least two bZIP transcription factors, bZIP60 and bZIP28, were found to regulate ER-stress [45], Interestingly, bZIP60 is translocated to the nucleus in a truncated form, similar to the activation mechanism of mammalian ATF6 [46], In agreement with a model that unifies ER-stress response and developmentally activated secretion, the cleaved form of bZIP60 was seen to accumulate in anther tapetal cells, which are known to secrete large amounts of proteins and lipids and whose ER is hypertrophied, as observed in ultrastructural analysis. These results suggest that bZIP60 and bZIP28 could be potential candidates for manipulating secretory functions in plant cells.

The second physiological situation under which plant cells resembles plasma cell differentiation is during seed development. In this case, plant cells activate storage protein production in ER-derived protein bodies or protein storage vacuoles. Among other changes, the preparation for active protein production includes an up-regulation of $\mathrm{BiP}$ and other chaperones. This activation of the ER may be interpreted as a
Deleted:

Deleted: plants,

Deleted: nd a

Formatted: Font: Italic

\begin{tabular}{l} 
Deleted: have been \\
Field Code Changed \\
\hline Deleted: [47] \\
Deleted: c \\
Field Code Changed \\
Deleted: $[48]$
\end{tabular}

Deleted: pollen 


\section{Two edges sword: delivery versus disposal}

Although extracellular secretion is the "natural" route for antibody production, it is not unusual to see $\mathrm{mAbs}$ accumulating in intracellular compartments such us the vacuole or proteins, since it precedes the actual up-regulation of storage proteins. In maize, the activation of storage protein biosynthesis during seed development is activated by opaque-2, also a bZIP transcription factor. Opaque-2 binds the promoter region of storage zein genes, and up-regulates a number of enzymes involved in nitrogen and carbon metabolism, favoring the new role of endosperm cells as "biofactory" [47, 48].

The influence of mAb production upon the plant endomembrane system has not \begin{tabular}{l} 
Deleted: $[49,50]$ \\
\hline Deleted: MAb
\end{tabular} been studied in detail. Nevertheless, all the observations indicate that plant-made antibodies recruit plant chaperones in an analogous way as they do in animal cells. The presence of immunoglobulin chains in plants is associated with an increase in BiP and PDI expression, and plant $\mathrm{BiP}$ has been shown to mediate folding of $\mathrm{IgG}$. BiP binds preferentially unfolded $\mathrm{H}$ chains which are then displaced by the presence of $\mathrm{L}$ chains [49]. These indications suggest that the activation of the secretory functions in the plant biofactories could positively influence mAb production. However the experience obtained from mammalian systems anticipates the requirement for coordinated upregulation of all downstream processing events including folding and assembly steps. Besides, it may not be such a straightforward strategy: while BiP overexpression seems to help to cope with drought stress in soybean [50] it has been reported to have detrimental effects on the accumulation of a recombinant T-cell pollen allergen in rice [511. A more systemic approach for the activation of plant secretion, perhaps involving Deleted: [51] Deleted: MAb regulatory elements shared with plant UPR may help in boosting antibody production.

Deleted: [52] Field Code Changed Deleted: i Field Code Changed Deleted: [53]
Deleted: MAb

Deleted: accumulate Deleted: as 
the ER. Interestingly, these are the compartments naturally used by plants cells (e.g. seed endosperm) to store proteins in the form of ER-derived protein bodies (PBs) and protein storage vacuoles (PSV). This rises the possibility to engineer these compartments as final destinations for plant-made mAbs. An interesting insight on this direction was provided by comparing the accumulation in tobacco leaves of anti-caries Guy's 13 antibody in two isotypes: IgG and a sIgG/A hybrid form. Murine $\operatorname{IgG}$ antibody, which was expressed in tobacco leaves at reasonable $1 \%$ TSP levels was efficiently secreted to the apoplast. Surprisingly, $\operatorname{sgA} / \mathrm{G}$ complex accumulated at levels up to $8 \%$ TSP. Although the differences in accumulation levels were initially attributed to the stability provided by SC, it was later observed that it was the accumulation in the vacuole and ER rather than the apoplast what could account in part for the higher level of sIgG/A production. Mistargeting to the vacuole was found to be provoked by a criptic vacuolar sorting signal located at the tailpiece of $\operatorname{IgG} / \mathrm{A}$ constant region $[52,53]$, Thus, jntracellular targeting and accumulation could be regarded as a potential mechanism to increase $\mathrm{mAb}$ productivity in plants. Unfortunately intracellular retention was accompanied by discrete degradation of IgG/A probably as a result of proteolytic activity in the vegetative (lytic) vacuole.

One of the peculiar characteristics of the plant secretory pathway is the presence of vacuoles, multipurpose organelles that often resemble the extracellular milieu in terms of protein trafficking. Recently, it has become established that targeting to the vacuole can follow two different routes. In the classical route, ER cargo is loaded to the Golgi apparatus and from there delivered into the vacuole in the presence of a vacuolar targeting signal. This classical route is followed by many hydrolases delivered to the lytic vacuole, as well as by seed storage proteins delivered to PSVs. Proteins following this route are decorated with complex glycans, a hallmark of their transit through the
Deleted: for protein storage

Deleted: The

Deleted: arises that these

Deleted: could be also engineered

Deleted: MAb Deleted: issue
Deleted: intracellula

Deleted: $r$

Deleted:

Deleted: MAb 
Golgi apparatus. It has been repeatedly observed, however, that many proteins, including recombinant antibodies engineered for secretion, ended up accumulating in the vacuole without the characteristic glycosylation patterns of the Golgi apparatus. This observation suggests the existence of an alternative shortcut to the classical route [54l. The determinants for secretion or vacuolar delivery are not yet fully understood, but the direct route from ER to the lytic vacuole may represent in some cases a sort of quality control mechanism for the disposal of improperly folded proteins. An extreme example of how complicated the subcellular delivery of a recombinant antibody may be is provided by the detailed localization studies of sIgA produced in rice endosperm. Here, subcellular targeting turned out to be dependent on the folded status of the polypeptides, with non-assembled chainş accumulating within ER-derived protein bodies while the assembled antibody, accumulated specifically in protein storage vacuoles $[20]$

This and similar results raise the possibility of designing specific targeting to subcellular compartments, namely vacuole or ER-derived bodies, for the accumulation of recombinant mAbs, following the path of seed storage proteins [55]. Retention in the ER can be easily induced by adding retention signals KDEL or HDEL. In fact, ERretention has been repeatedly reported to enhance accumulation of recombinant antibodies in plants, most especially in the case of antibody fragments highly dependent on disulfide bridges for proper folding [56]. For certain proteins, ER milieu seems to provide a certain degree of stability, which is lost once the protein is delivered to the Golgi apparatus towards secretion. Another often claimed advantage of mAb retention in the ER is the absence of Golgi-derived complex glycosylation that could potentially cause immunogenicity in target organisms. mAbs free of complex glycans can be also targeted to the vacuole by engineering cleavable membrane anchored fusions to integral

Deleted: MAb

Deleted: in

Deleted: MAb

Deleted: be 
Deleted: proposed

proteins present in the Golgi-independent pathway to the vacuole, as recently proposed [57].

\section{Cut into pieces: stability, proteolysis and subcellular localization}

Literature on plant-made $\mathrm{mAb}$ is loaded with successful stories that may lead to the conclusion that all antibodies are well expressed in plants. However this is probably an observational selection effect; it is common experience to find large differences in expression levels among different $m A$ Abs and, although not often reported, a number of difficult-to-express $\underline{m A b s}$ yield unexpectedly poor expression levels. These striking differences were often attributed to positional effects of the transgenes. However with the use of transient methodologies (that will be discussed below), where positional effects can be discarded, it has become evident that stability differences among $m A b$ do exist. This effect is even more striking when antibody variable regions are imported from combinatorial libraries (e.g. phage display selection). In an experience where 10 full-size chicken antibodies derived from phage display where transiently expressed in $N$. benthamiana leaves, only six of them showed detectable accumulation levels in western analysis [37l An explanation for this low success rate is that Ig variable domains selected by phage display (in contrast to hybridoma-selected lines) have never encountered ER-folding and quality control systems and may therefore be inadequately adapted to it. In mammalian cells, improperly folded Ig domains are retained longer in the ER bound to BiP, and are finally translocated to the cytoplasm by the ER-quality control mechanism (ERAD) and ultimately degraded via the proteosome. Plant ERADlike systems are active in degrading misfolded proteins. Recently it has been demonstrated that allelic forms of barley MLO protein which differ in single amino-acid substitutions are specifically degraded via ERAD in a process that requires proteasome

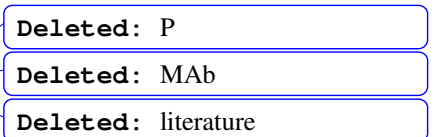

Deleted: literature

Deleted: MAb

Deleted: MAb

Deleted:

Deleted: MAb

Deleted: [35]

Deleted: was

Deleted: which 
function [581. Interestingly, this situation resembles that of variable antibody chains where idiotype differences are often determined by a few amino-acid changes. Plant ERAD-like mechanism is assumed to play a role in the degradation of improperly folded antibody chains; however this remains to be experimentally established.

Another often misreported problem is the presence of small antibody fragments, probably resulting from discrete proteolytic degradation of $\mathrm{HC}$ and LC. $\mathrm{mAb}$ fragments are especially difficult to remove by affinity purification and may represent a mayor drawback in the optimization process. Generation of antibody fragments smaller than the intact molecule is a common observation in plant expression systems $[19,59,60]$, A detailed analysis of the antibody fragments produced by a secreted $\operatorname{IgG}$ in a root expression system showed that they were not caused by antibody degradation during protein extraction. Two smaller fragments of 50 - and $80-\mathrm{kDa}$ were identified as the products of protease activity in the apoplast, whereas two additional fragments of 120and $135-\mathrm{kDa}$ were most likely the products of proteolytic degradation along the secretory pathway outside the endoplasmic reticulum (ER); the carbohydrate residues of the $135-\mathrm{kDa}$ antibody suggested that this fragment was formed between the ER and Golgi [61] A deeper understanding of the plant protease activities responsible for antibody degradation is needed to minimize the detrimental effect of proteolysis in plant mAb production.

Another particularly interesting subcellular localization for plant molecular farming is the plastid, particularly as a result of transplastomic approach due to their capacity to produce high yields of recombinant proteins. However plastids, lacking endomembrane system, are unable to synthesize fully assembled, glycosylated antibodies. In an attempt to produce an antibody structure resembling full-size $\mathrm{mAb}$ in algae chloroplasts, a single chain IgA-like molecule was engineered consisting of a complete human $\alpha \mathrm{HC}_{-}$

Deleted: of

Field Code Changed

Deleted: [61]

Deleted: MAb

Deleted: in 
covalently linked to a human LC variable region. The chimeric single chain IgA was adequately folded in the plastid and displayed IgA-like binding activity $[62\rceil$. However it should be noted that in the absence of glycosylation such antibodies are unable to bind Fc receptors and activate effector functions, and this poses a limitation in the range of potential applications of plastid-derived antibodies.

\section{Antibody decoration: advances in plant glyco-engineering}

Antibodies are highly glycosylated in their constant regions. As much as variable regions determine $\mathrm{mAb}$ binding activity, glycosylation of constant regions determine many other important antibody features such as resistance to protease degradation, half life in serum and, most importantly for mAb-based immunotherapy, effector's function by binding Fc receptors. Plant-made antibodies are glycosylated following the basic principles of the eukaryotic secretion machinery (Fig. 3). ER-translocated nascent peptides are decorated in certain Asn residues with an oligosaccharide rich in mannose, Later in the process, mannose rich oligosaccharides are trimmed by ER-resident mannosidase and subsequently engaged by $\mathrm{N}$-acetyl-glucosamine transferase, which adds terminal $\mathrm{N}$-acetylglucosamine residues forming a typical biantennary complex that enters the early Golgi . Up to this point, plant glycosylation does not differ from that in animals. Differences however do occur when proteins enter the Golgi apparatus, where the formation of complex $\mathrm{N}$-glycans takes place. In humans, biantennary complexes are specifically decorated with $\alpha$ 1-6 fucose, $\beta$ 1-4 galactose, and syalic acid. All three residues are absent in plants, which instead decorate with $\alpha$ 1-3 fucose, $\beta$ 1-2 xylose, and sometimes a terminal structure known as Lewis a $(\beta(1,3) \mathrm{Gal}[\alpha(1,4) \mathrm{Fuc}])($ see $[63-$ 65l for recent reviews on this issue).

Deleted: y fragments

Deleted: s

Deleted: MAb 
It is arguable to what extent "humanization" of plant-made $\mathrm{mAb}$ glycosylation patterns jis strictly necessary, or if this will depend on the intended application. The data of possible allergenicity of plant specific glycans is controversial. Although no glycanspecific antibodies were generated in mice when exposed to plant-derived antibodies 166] this effect can not be generalized as it seems to be species-specific [63, 64, 67] As a precautionary principle, especially for recombinant antibodies indented for systemic use, the current tendency is to imitate human glycosylation in plants. To this end, a two-step design has been followed. The first one is the knock out of those plant enzymes adding plant-specific residues, namely $\alpha$ 1-3 fucosyl transferase (FT) and $\beta$ 1-2 xylosyl transferase (XT). $\Delta \mathrm{FT} / \mathrm{XT}$ plants have been engineered either using null mutants or RNAi technology in several species as Arabidopsis, tobacco and Lemma minor. In this latter system, North Carolina-based company Biolex reported the production of homogenously glycosilated antibodies devoid of plant specific glycans [68] Nevertheless, the presence of $\beta$ 1-4 galactose and specially syalic acid as terminal residues in animal glycosylation_patterns strongly determines the half life of the antibody in the serum, and therefore the engineering of plants with human specific transferases is also a desirable step. First attempts to knock in $\beta$ 1-4 galactosyl transferase (GalT) were only partially successful as they rendered very heterogeneous decorations $\ 69][70]$, but the result was much better when GalT was targeted to the late Golgi. The crossing of GalT knocked in plants with $\Delta \mathrm{FT} / \mathrm{XT}$ mutants generated a tobacco line with a humanized glycosylation pattern. These plants were used, in combination with Icon's magnifection system (see below), for the production of highly homogeneous humanized antibodies $[71\rceil$ Interestingly, antibodies produced in $\Delta \mathrm{FT} / \Delta \mathrm{XT} / \mathrm{GalT}$ plants were more effective than their CHO-made counterparts in neutralizing HIV infection, apparently due to their homogeneous glycosylation pattern
Deleted: MAb

Deleted: are

Deleted: on

Deleted: , and apparently species-dependent.

Deleted: a

Deleted: (Chargelegue

Deleted: et al., 2000)

Deleted:

Deleted:

Deleted: [63,66].

Deleted: antibody

Formatted: Font: Italic
Deleted: so

Deleted: a second step on the design of glycol-humanized plants consisting on the knock in of the

Deleted: enzymes

Deleted: ,

Formatted: Font: Italic

Deleted: (ref)

Formatted: Font: Italic 


\section{Little and fast or lots and slow: transient versus stable transformation} technologies

Scalability was traditionally considered a main advantage of plant platforms. Unexpectedly, some of the most promising plant-based expression systems currently propose speed rather than scalability as their main advantage. Initially, transient expression technologies were based solely on recombinant viral vectors, which spread recombinant protein production as they infect the plant (see 741 for a review on viral expression systems). However, the relatively big size of the antibody chains imposes a handicap in viral replication and movement, and clonal exclusion precludes the coinfection in a single cell with two viral vectors containing heavy and light chains. Particularly interesting was the work made with Tobacco Mosaic Virus (TMV) in Large Scale Biology Corporation (LSB). This company developed a rapid TMV-based expression system for the production of anti-idiotypic $\mathrm{scFv}$ antibodies against non- 
maintain itself in the market. In a certain way, LSC anticipated the current boom of transient expression technologies in plants.

Most current transient technologies are based on Agrobaterium tumefaciens and its high efficiency to transfer DNA to plant cells in leaf tissues_ and other organs like roots or fruits [76], With this technique, Agrobacterium suspension cultures are infiltrated by pressure into the intercellular space of leaf mesophyll, efficiently transferring its $\mathrm{T}$ DNA to the plant cell nucleus (a technique known as agroinfiltration). Recombinant gene constructs are actively transcribed and translated in a temporal window that begins approximately two days post-inoculation and ceases approximately 3-5 days later. It has been shown that silencing suppressors may burst expression at its maximum and delay the decline in expression, indicating that transient expression is being limited by silencing rather than by T-DNA degradation [77l, One of the most attractive features of agroinfiltration is that the efficiency of co-delivery is very high, allowing easy cotransformation of $\mathrm{H}$ - and L-chain constructs for antibody production. Moreover, transgene expression levels obtained by agroinfiltration are in the range of the best stable transformed lines. This provides acceptable production levels that have become the basis of some of the technology employed by companies as Canada-based Medicago Inc $[781$,

A major breakthrough in transient technologies was developed by Icon Genetics group and their magnifection technique. Magnifection takes the best of two worlds by combining the amplification power of viral vectors with the highly contained cotransformation efficiency of agroinfiltration. This methodology is based on a viral replicon derived from TMV, which is devoid of the capsid protein gene and therefore lacks its capacity to move systemically. The replicative unit was deconstructed in two pieces, with one of them designed to harbor a gene of interest. Each viral segment,

Deleted: , Deleted: also Field Code Changed

Deleted: [73] Field Code Changed
Deleted: of 
which is flanked by a homologous recombination site, is inserted in a separate expression cassette and introduced in a separate binary vector. Both vectors, together with a third one containing a recombinase, are co-delivered into plant cells using agroinfiltration. The above mentioned high co-tranformation rate of this methodology ensures that a number of cells will become transformed with all three constructs simultaneously. In the event of triple co-transformation, recombinase activity ensures that a complete viral replicon will be reconstructed within the cell. The reassembled RNA unit contains, together with the gene of interest, a RNA-dependent-RNApolymerase, that ensures gene amplification, and a movement protein (MP), which ensures cell-to-cell spreading of the replicon throughout the entire agroinfiltrated leaf $[79,80 \downarrow$ Since RNA viruses do not enter the nucleus in its natural life cycle, Icon's vector was elegantly tailored for its artificial nucleus-to cytoplasm passage by addition of introns and removal of cryptic splicing sites [81] As a result, its performance was significantly improved reaching levels of up to $40 \%$ TSP for certain recombinant proteins.

Despite its impressive performance, Icon's magnifection technology faced the same problem as other viral systems for $\mathrm{mAb}$ production. Co-infection within a single cell of viral replicons containing $\mathrm{H}$ and $\mathrm{L}$ chains is a rare event due to clonal exclusion. The problem was solved by introducing a second, non-competing virus in the game. It was known for long in plant virology that viral co-infection may occur provided that both players do not compete for the same cell resources as is the case for Potato Virus $\mathrm{X}$ (PVX) and TMV (Fig. 4). Using complementary vectors derived from these viruses, $\mathrm{H}$ and $\mathrm{L}$ chains were successfully co-expressed in $N$. benthamiana leaves, reaching commercially viable levels of up to $10 \%$ TSP $[82 \downarrow$ It is noteworthy that the cell Field Code Changed Deleted: [78]
Deleted: [75, 76]

Field Code Changed

Deleted: [77]

Field Code Changed 
circulating cargo without collapsing, and it is tempting to speculate that UPR-like adaptations discussed above could be taking place in response to the presence of viral proteins in the cell. A profile of PR expression could indicate if a UPR-like reaction is helping the ER to cope with $\mathrm{mAb}$ cargo in maginfected leaves. Icon Genetics was acquired by Bayer Innovation and it is currently attempting to bring to the market the concept of personalized vaccines against non-Hodgkin's lymphoma once ventured by LSB.

The use of transient methodologies is gaining pace and new and improved methodologies are continuously emerging. Recently, Sainsbury and Lomonossof reported a strikingly simple methodology based on Cowpea Mosaic Virus (CPMV) [83, 84l. The system, which also makes use of Agrobacterium as shuttle system, achieves extremely high levels of protein production without viral replication. It is based on the ability of a mutated version of 5 UTR of CPMV RNA2 to drive high levels of transcription. The absence of viral replication excludes clonal exclusion allowing high levels of co-transformation and reaching IgG expression levels of 10\% TSP with a very simplified method. This and other transient rapid methodologies will surely have a role to play in responding to the increasing needs for rapid, tailor-made recombinant proteins.

\section{Summary and perspectives}

As plant biotechnology develops, the restrictions initially hampering the Formatted: Font: Bold Formatted: Indent: First line: 0 pt development of plant-made recombinant proteins are being eased. This has brought a renewed interest of companies and research groups in plant-made antibodies. Transgenic technology has improved during the last 20 years, with many more species being routinely transformed and simpler and more efficient methods in place $[85,86]$. 
Downstream processing of plant extracts, which was initially neglected by plant biotechnologists, and turned to be a nightmare for the commercialization of the socalled "plantibodies", has been conveniently addressed by several companies, which have substantially improved and scaled up the purification protocols [87].

While some old concerns are gradually being addressed, new opportunities arise from previously unforeseen technologies. Transient expression protocols provide the required speed for many modern manufacturing processes, as those related to custom production for individualized therapies. The full "humanization" of plant glycosylation patterns is underway, and those steps accomplished so far have produced recombinant mAbs with superior neutralizing activities when compared with competing platforms $[71,88]$. Finally, as plant recombinant products are gradually available, current $\underline{\text { restrictions in the regulatory framework may well be relaxed, opening new }}$ opportunities. Hopefully, this and other regulatory changes, like the recent clearance for commercialization of partially purified botanical mixtures [89], may pave the way for $\underline{\text { large scale production of cheap prophylactic products based on plant-made mAbs, one }}$ of the big promises of this technology.

\section{Acknowledgements} 60923. 
11 Figure Legends

Figure_1._Antibody formats manufactured in the plant cell. (A) Schematic representation of a typical human $\operatorname{IgG}$ antibody, showing constant heavy (CH1-3), constant light $(\mathrm{CL})$, variable heavy $(\mathrm{VH})$ and variable light $(\mathrm{VL})$ domains. The structure of IgG-derived antibody fragments is also shown. (B) Representation of a camelid antibody comprising only heavy chains but full antigen binding capacity. (C) Comparison of full length antibody with different antibody fragments and fusions expressed in plants. ScFv: single chain antibody fragment; VHH: single chain camelid antibody (nanobody); scFv-Fc single chain full-size antibody proposed for plastid expression; scFv-elastin: single chain-elastin fusions.

Figure 2. Natural biosynthesis of secretory IgA in mucosal surfaces. Polymeric $\operatorname{IgA}$ (pIgA) (composed of $\operatorname{IgA}$ and $\mathrm{J}$ chain) is secreted by plasma cells at the basolateral surface of mucosal epithelium. The Poly-immunoglogulin receptor (pIgR) mediates the transcitosis of $\operatorname{IgA}$ throughout the epithelium cell. At the luminal side, pIgR is cleaved releasing pIgA bound to its extracellular portion, the Secretory Component (SC). The final molecular complex, composed of IgA, Jchain and SC is known as secretory IgA $(\operatorname{sIgA})$.

Figure 3. N-Glycosylation patterns in plants and animals. Schematic representation of the formation of typical complex glycans in the Golgi apparatus of animals (upper panel) and plants (lower panel).
Deleted: 10

Deleted: 


\section{References}

[1] Walsh, G., Current Status of Biopharmaceuticals: Approved Products and Trends in Approvals, in Modern Biopharmaceuticals: Design, Development and Optimization, J. Knäblein, Editor. 2005, WILEY-VCH Verlag GmbH \& Co. KGaA: Weinheim.

[2] Molowa, D., Mazanet, R., The state of biopharmaceutical manufacturing. Biotechnol. Annu. Rev. 2003, 9, 295-301.

[3] Kamarck, M. E., Building biomanufacturing capacity--the chapter and verse. Nat Biotechnol. 2006, 24, (5), 503-5.

[4] Mazor, Y., Van Blarcom, T., Mabry, R., Iverson, B. L. et al., Isolation of engineered, full-length antibodies from libraries expressed in Escherichia coli. Nat Biotechnol. 2007, 25, (5), 563-5.

[5] Menzella, H. G., Reid, R., Carney, J. R., Chandran, S. S. et al., Combinatorial polyketide biosynthesis by de novo design and rearrangement of modular polyketide synthase genes. Nat Biotechnol. 2005, 23, (9), 1171-6.

[6] Hamilton, S. R., Gerngross, T. U., Glycosylation engineering in yeast: the advent of fully humanized yeast. Curr. Opin. Biotechnol. 2007, 18, (5), 387-92. 
[7] Wurm, F. M., Production of recombinant protein therapeutics in cultivated mammalian cells. Nat Biotechnol. 2004, 22, (11), 1393-8.

[8] Zhu, L., van de Lavoir, M. C., Albanese, J., Beenhouwer, D. O. et al., Production of human monoclonal antibody in eggs of chimeric chickens. Nat Biotechnol. 2005, 23, (9), 1159-69.

[9] Berger, I., Fitzgerald, D. J., Richmond, T. J., Baculovirus expression system for heterologous multiprotein complexes. Nat. Biotechnol. 2004, 22, (12), 15831587.

[10] Ehrlich, P., Croonian Lecture: On Immunity with Special Reference to Cell Life. Proc. R. Soc. Lond. 1899, 66, 424-448; .

[11] Dübel, S., Therapeutic Antibodies - From Past to Future, in Handbook of Therapeutic Antibodies, S. Dübel, Editor. 2007, Wiley-VCH Verlag GmbH \& Co. KGaA: Weinheim.

[12] McCafferty, J., Griffiths, A. D., Winter, G., Chiswell, D. J., Phage antibodies: filamentous phage displaying antibody variable domains. Nature. 1990, 348, (6301), 552-4.

[13] Hiatt, A., Cafferkey, R., Bowdish, K., Production of Antibodies in Transgenic Plants. Nature. 1989, 342, (6245), 76-78.

[14] Stoger, E., Sack, M., Fischer, R., Christou, P., Plantibodies: applications, advantages and bottlenecks. Curr. Opin. Biotechnol. 2002, 13, 161-166.

[15] Ma, J. K. C., Drake, P. M. W., Christou, P., The production of recombinant pharmaceutical proteins in plants. Nat. Rev. Genet. 2003, 4, (10), 794-805.

[16] Schillberg, S., Fischer, R., Emans, N., 'Molecular farming' of antibodies in plants. Naturwissenschaften. 2003, 90, (4), 145-155.

[17] Ko, K., Brodzik, R., Steplewski, Z., Production of antibodies in plants: approaches and perspectives. Curr. Top. Microbiol. Immunol. 2009, 332, 55-78.

[18] Smith, M. D., Antibody production in plants. Biotechnol. Adv. 1996, 14, (3), 267-81.

[19] van Engelen, F. A., Schouten, A., Molthoff, J. W., Roosien, J. et al., Coordinate expression of antibody subunit genes yields high levels of functional antibodies in roots of transgenic tobacco. Plant Mol Biol. 1994, 26, (6), 1701-10.

[20] Nicholson, L., Gonzalez-Melendi, P., van Dolleweerd, C., Tuck, H. et al., A recombinant multimeric immunoglobulin expressed in rice shows assemblydependent subcellular localization in endosperm cells. Plant Biotechnol J. 2005, 3, (1), 115-27.

[21] Ramessar, K., Rademacher, T., Sack, M., Stadlmann, J. et al., Cost-effective production of a vaginal protein microbicide to prevent HIV transmission. Proc Natl Acad Sci U S A. 2008, 105, (10), 3727-32.

[22] Rademacher, T., Sack, M., Arcalis, E., Stadlmann, J. et al., Recombinant antibody 2G12 produced in maize endosperm efficiently neutralizes HIV-1 and contains predominantly single-GlcNAc N-glycans. Plant Biotechnol J. 2008, 6, (2), 189-201.

[23] Fiedler, U., Phillips, J., Artsaenko, O., Conrad, U., Optimization of scFv antibody production in transgenic plants. Immunotechnology. 1997, 3, (3), 20516.

[24] Muyldermans, S., Cambillau, C., Wyns, L., Recognition of antigens by singledomain antibody fragments: the superfluous luxury of paired domains. Trends Biochem. Sci. 2001, 26, (4), 230-5. 
[25] Jobling, S. A., Jarman, C., Teh, M. M., Holmberg, N. et al., Immunomodulation of enzyme function in plants by single-domain antibody fragments. Nat Biotechnol. 2003, 21, (1), 77-80.

[26] Floss, D. M., Falkenburg, D., Conrad, U., Production of vaccines and therapeutic antibodies for veterinary applications in transgenic plants: an overview. Transgenic Res. 2007, 16, (3), 315-32.

[27] Jahn, D., Matros, A., Bakulina, A. Y., Tiedemann, J. et al., Model structure of the immunodominant surface antigen of Eimeria tenella identified as a target for sporozoite-neutralizing monoclonal antibody. Parasitol Res. 2009, 105, (3), 65568.

[28] Zimmermann, J., Saalbach, I., Jahn, D., Giersberg, M. et al., Antibody expressing pea seeds as fodder for prevention of gastrointestinal parasitic infections in chickens. BMC Biotechnol. 2009, 9, 79.

[29] Obregon, P., Chargelegue, D., Drake, P. M., Prada, A. et al., HIV-1 p24immunoglobulin fusion molecule: a new strategy for plant-based protein production. Plant Biotechnol J. 2006, 4, (2), 195-207.

[30] Floss, D. M., Sack, M., Stadlmann, J., Rademacher, T. et al., Biochemical and functional characterization of anti-HIV antibody-ELP fusion proteins from transgenic plants. Plant Biotechnol J. 2008, 6, (4), 379-91.

[31] Floss, D. M., Sack, M., Arcalis, E., Stadlmann, J. et al., Influence of elastin-like peptide fusions on the quantity and quality of a tobacco-derived human immunodeficiency virus-neutralizing antibody. Plant Biotechnol J. 2009,

[32] Chargelegue, D., Drake, P. M., Obregon, P., Prada, A. et al., Highly immunogenic and protective recombinant vaccine candidate expressed in transgenic plants. Infect. Immun. 2005, 73, (9), 5915-22.

[33] Corthesy, B., Spertini, F., Secretory immunoglobulin A: From mucosal protection to vaccine development. Biol. Chem. 1999, 380, (11), 1251-1262.

[34] Ma, J. K., Hiatt, A., Hein, M., Vine, N. D. et al., Generation and assembly of secretory antibodies in plants. Science. 1995, 268, (5211), 716-9.

[35] Ma, J. K. C., Hikmat, B. Y., Wycoff, K., Vine, N. D. et al., Characterization of a recombinant plant monoclonal secretory antibody and preventive immunotherapy in humans. Nature Medicine. 1998, 4, (5), 601-606.

[36] Larrick, J. W., Yu, L., Naftzger, C., Jaiswal, S. et al., Production of secretory IgA antibodies in plants. Biomol. Eng. 2001, 18, (3), 87-94.

[37] Wieland, W. H., Lammers, A., Schots, A., Orzaez, D. V., Plant expression of chicken secretory antibodies derived from combinatorial libraries. J. Biotechnol. 2006, 122, (3), 382-91.

[38] Casadevall, A., Dadachova, E., Pirofski, L. A., Passive antibody therapy for infectious diseases. Nat. Rev. Microbiol. 2004, 2, (9), 695-703.

[39] Harding, H. P., Calfon, M., Urano, F., Novoa, I. et al., Transcriptional and translational control in the Mammalian unfolded protein response. Annu. Rev. Cell Dev. Biol. 2002, 18, 575-99.

[40] Gass, J. N., Gunn, K. E., Sriburi, R., Brewer, J. W., Stressed-out B cells? Plasma-cell differentiation and the unfolded protein response. Trends Immunol. 2004, 25, (1), 17-24.

[41] Becker, E., Florin, L., Pfizenmaier, K., Kaufmann, H., An XBP-1 dependent bottle-neck in production of $\operatorname{IgG}$ subtype antibodies in chemically defined serum-free Chinese hamster ovary (CHO) fed-batch processes. J. Biotechnol. 2008, 135, (2), 217-23. 
[42] Wang, S., Narendra, S., Fedoroff, N., Heterotrimeric G protein signaling in the Arabidopsis unfolded protein response. Proc Natl Acad Sci U S A. 2007, 104, (10), 3817-22.

[43] Vitale, A., Boston, R. S., Endoplasmic reticulum quality control and the unfolded protein response: insights from plants. Traffic. 2008, 9, (10), 1581-8.

[44] Wang, D., Weaver, N. D., Kesarwani, M., Dong, X., Induction of protein secretory pathway is required for systemic acquired resistance. Science. 2005, 308, (5724), 1036-40.

[45] Iwata, Y., Koizumi, N., An Arabidopsis transcription factor, AtbZIP60, regulates the endoplasmic reticulum stress response in a manner unique to plants. Proc Natl Acad Sci U S A. 2005, 102, (14), 5280-5.

[46] Iwata, Y., Fedoroff, N. V., Koizumi, N., Arabidopsis bZIP60 is a proteolysisactivated transcription factor involved in the endoplasmic reticulum stress response. Plant Cell. 2008, 20, (11), 3107-21.

[47] Schmidt, R. J., Ketudat, M., Aukerman, M. J., Hoschek, G., Opaque-2 is a transcriptional activator that recognizes a specific target site in $22-\mathrm{kD}$ zein genes. Plant Cell. 1992, 4, (6), 689-700.

[48] Vitale, A., Ceriotti, A., Protein quality control mechanisms and protein storage in the endoplasmic reticulum. A conflict of interests? Plant Physiol. 2004, 136, (3), 3420-6.

[49] Nuttall, J., Vine, N., Hadlington, J. L., Drake, P. et al., ER-resident chaperone interactions with recombinant antibodies in transgenic plants. Eur. J. Biochem. 2002, 269, (24), 6042-6051.

[50] Valente, M. A., Faria, J. A., Soares-Ramos, J. R., Reis, P. A. et al., The ER luminal binding protein $(\mathrm{BiP})$ mediates an increase in drought tolerance in soybean and delays drought-induced leaf senescence in soybean and tobacco. $J$. Exp. Bot. 2009, 60, (2), 533-46.

[51] Yasuda, H., Hirose, S., Kawakatsu, T., Wakasa, Y. et al., Overexpression of BiP has inhibitory effects on the accumulation of seed storage proteins in endosperm cells of rice. Plant Cell Physiol. 2009, 50, (8), 1532-43.

[52] Hadlington, J. L., Santoro, A., Nuttall, J., Denecke, J. et al., The C-terminal extension of a hybrid immunoglobulin $A / G$ heavy chain is responsible for its golgi-mediated sorting to the vacuole. Mol. Biol. Cell. 2003, 14, (6), 2592-2602.

[53] Frigerio, L., Vine, N. D., Pedrazzini, E., Hein, M. B. et al., Assembly, secretion, and vacuolar delivery of a hybrid immunoglobulin in plants. Plant Physiol. 2000, 123, (4), 1483-1493.

[54] Vitale, A., Galili, G., The endomembrane system and the problem of protein sorting. Plant Physiol. 2001, 125, (1), 115-8.

[55] Torrent, M., Llop-Tous, I., Ludevid, M. D., Protein body induction: a new tool to produce and recover recombinant proteins in plants. Methods Mol. Biol. 2009, 483, 193-208.

[56] Schouten, A., Roosien, J., van Engelen, F. A., de Jong, G. A. et al., The Cterminal KDEL sequence increases the expression level of a single-chain antibody designed to be targeted to both the cytosol and the secretory pathway in transgenic tobacco. Plant Mol Biol. 1996, 30, (4), 781-93.

[57] Wang, J., Miao, Y., Jiang, L., Response to Gomord et al.: Golgi-bypassing: delivery of biopharmaceutical proteins to protein storage vacuoles in plant bioreactors. Trends Biotechnol. 2006, 24, (4), 147-9. 
[58] Muller, J., Piffanelli, P., Devoto, A., Miklis, M. et al., Conserved ERAD-like quality control of a plant polytopic membrane protein. Plant Cell. 2005, 17, (1), 149-63.

[59] De Neve, M., De Loose, M., Jacobs, A., Van Houdt, H. et al., Assembly of an antibody and its derived antibody fragment in Nicotiana and Arabidopsis. Transgenic Res. 1993, 2, (4), 227-37.

[60] Khoudi, H., Laberge, S., Ferullo, J. M., Bazin, R. et al., Production of a diagnostic monoclonal antibody in perennial alfalfa plants. Biotechnol. Bioeng. 1999, 64, (2), 135-43.

[61] Sharp, J. M., Doran, P. M., Characterization of monoclonal antibody fragments produced by plant cells. Biotechnol. Bioeng. 2001, 73, (5), 338-46.

[62] Mayfield, S. P., Franklin, S. E., Lerner, R. A., Expression and assembly of a fully active antibody in algae. Proc Natl Acad Sci U S A. 2003, 100, (2), 438-42.

[63] Ko, K., Ahn, M. H., Song, M., Choo, Y. K. et al., Glyco-engineering of biotherapeutic proteins in plants. Mol. Cells. 2008, 25, (4), 494-503.

[64] Saint-Jore-Dupas, C., Faye, L., Gomord, V., From planta to pharma with glycosylation in the toolbox. Trends Biotechnol. 2007, 25, (7), 317-23.

[65] Gomord, V., Sourrouille, C., Fitchette, A. C., Bardor, M. et al., Production and glycosylation of plant-made pharmaceuticals: the antibodies as a challenge. Plant Biotechnol J. 2004, 2, (2), 83-100.

[66] Chargelegue, D., Vine, N. D., van Dolleweerd, C. J., Drake, P. M. et al., A murine monoclonal antibody produced in transgenic plants with plant-specific glycans is not immunogenic in mice. Transgenic Res. 2000, 9, (3), 187-94.

[67] Jin, C., Altmann, F., Strasser, R., Mach, L. et al., A plant-derived human monoclonal antibody induces an anti-carbohydrate immune response in rabbits. Glycobiology. 2008, 18, (3), 235-41.

[68] Cox, K. M., Sterling, J. D., Regan, J. T., Gasdaska, J. R. et al., Glycan optimization of a human monoclonal antibody in the aquatic plant Lemna minor. Nat Biotechnol. 2006, 24, (12), 1591-7.

[69] Palacpac, N. Q., Yoshida, S., Sakai, H., Kimura, Y. et al., Stable expression of human beta1,4-galactosyltransferase in plant cells modifies $\mathrm{N}$-linked glycosylation patterns. Proc Natl Acad Sci U S A. 1999, 96, (8), $4692-7$.

[70] Bakker, H., Bardor, M., Molthoff, J. W., Gomord, V. et al., Galactose-extended glycans of antibodies produced by transgenic plants. Proc Natl Acad Sci U S A. 2001, 98, (5), 2899-904.

[71] Strasser, R., Castilho, A., Stadlmann, J., Kunert, R. et al., Improved Virus Neutralization by Plant-produced Anti-HIV Antibodies with a Homogeneous \{beta\}1,4-Galactosylated N-Glycan Profile. J. Biol. Chem. 2009, 284, (31), 20479-85.

[72] Jarvis, D. L., Developing baculovirus-insect cell expression systems for humanized recombinant glycoprotein production. Virology. 2003, 310, (1), 1-7.

[73] Paccalet, T., Bardor, M., Rihouey, C., Delmas, F. et al., Engineering of a sialic acid synthesis pathway in transgenic plants by expression of bacterial Neu5Acsynthesizing enzymes. Plant Biotechnol J. 2007, 5, (1), 16-25.

[74] Lico, C., Chen, Q., Santi, L., Viral vectors for production of recombinant proteins in plants. J Cell Physiol. 2008, 216, (2), 366-77.

[75] McCormick, A. A., Reinl, S. J., Cameron, T. I., Vojdani, F. et al., Individualized human $\mathrm{scFv}$ vaccines produced in plants: humoral anti-idiotype responses in vaccinated mice confirm relevance to the tumor Ig. J. Immunol. Methods. 2003, 278, (1-2), 95-104. 
[76] Orzaez, D., Mirabel, S., Wieland, W. H., Granell, A., Agroinjection of tomato fruits. A tool for rapid functional analysis of transgenes directly in fruit. Plant Physiol. 2006, 140, (1), 3-11.

[77] Voinnet, O., Rivas, S., Mestre, P., Baulcombe, D., An enhanced transient expression system in plants based on suppression of gene silencing by the p19 protein of tomato bushy stunt virus. Plant J. 2003, 33, (5), 949-956.

[78] D'Aoust, M. A., Lavoie, P. O., Belles-Isles, J., Bechtold, N. et al., Transient expression of antibodies in plants using syringe agroinfiltration. Methods Mol. Biol. 2009, 483, 41-50.

[79] Gleba, Y., Klimyuk, V., Marillonnet, S., Magnifection--a new platform for expressing recombinant vaccines in plants. Vaccine. 2005, 23, (17-18), 2042-8.

[80] Marillonnet, S., Giritch, A., Gils, M., Kandzia, R. et al., In planta engineering of viral RNA replicons: efficient assembly by recombination of DNA modules delivered by Agrobacterium. Proc Natl Acad Sci U S A. 2004, 101, (18), 6852-7.

[81] Marillonnet, S., Thoeringer, C., Kandzia, R., Klimyuk, V. et al., Systemic Agrobacterium tumefaciens-mediated transfection of viral replicons for efficient transient expression in plants. Nat. Biotechnol. 2005, 23, (6), 718-723.

[82] Giritch, A., Marillonnet, S., Engler, C., van Eldik, G. et al., Rapid high-yield expression of full-size IgG antibodies in plants coinfected with noncompeting viral vectors. Proc Natl Acad Sci U S A. 2006, 103, (40), 14701-6.

[83] Sainsbury, F., Thuenemann, E. C., Lomonossoff, G. P., pEAQ: versatile expression vectors for easy and quick transient expression of heterologous proteins in plants. Plant Biotechnol J. 2009, 7, (7), 682-93.

[84] Sainsbury, F., Lomonossoff, G. P., Extremely high-level and rapid transient protein production in plants without the use of viral replication. Plant Physiol. 2008, 148, (3), 1212-8.

[85] Zhu, C., Naqvi, S., Breitenbach, J., Sandmann, G. et al., Combinatorial genetic transformation generates a library of metabolic phenotypes for the carotenoid pathway in maize. Proc Natl Acad Sci U S A. 2008, 105, (47), 18232-7.

[86] Shewry, P. R., Jones, H. D., Halford, N. G., Plant biotechnology: transgenic crops. Adv. Biochem. Eng. Biotechnol. 2008, 111, 149-86.

[87] Rybicki, E. P., Plant-produced vaccines: promise and reality. Drug Discov. Today. 2009, 14, (1-2), 16-24.

[88] Castilho, A., Pabst, M., Leonard, R., Veit, C. et al., Construction of a functional CMP-sialic acid biosynthesis pathway in Arabidopsis. Plant Physiol. 2008, 147, (1), 331-9.

[89] Chen, S. T., Dou, J., Temple, R., Agarwal, R. et al., New therapies from old medicines. Nat Biotechnol. 2008, 26, (10), 1077-83. 
Page 11: [1] Deleted

dorzaez

10/21/2009 6:14:00 PM

In their natural biofactories, the lymphocytes, antibodies are synthesized through the

cell endomembrane system. Antibody synthesis requires coordinated expression, folding and assembly of $\mathrm{H}$ and $\mathrm{L}$ chains. First, the corresponding mRNAs are matured and translated in the rough ER; then their nascent polypeptides are translocated into the ER and the N-terminal signal peptide is subsequently cleaved; folding is assisted by ER resident chaperones as the Immunoglobulin Heavy Chain Binding Protein (BiP) [37]. Besides, the Endoplasmic Reticulum Associated Protein Degradation (ERAD) quality control mechanism ensures that unfolded antibody chains are removed from the ER and degraded via the proteosome [38]. Finally, antibody chains are linked together by disulfide bonds established by ER-resident protein disulfide isomerase (PDI) [39].

In artificial systems such as $\mathrm{CHO}$ cells, several genetic strategies have been followed to increase MAb production. This includes engineering of anti-apoptotic factors to inhibit cell death in high density cultures, an approach that can be directly translated to plant cell suspension systems but possibly not to transgenic plants. A second obvious strategy consists in increasing gene expression by different means, like raising recombinant gene copy number, using more active promoters or targeting recombinant DNA to active transcriptional sites. These approaches, which do have a clear parallel in plants, have been only partially successful. It is generally accepted that MAb yield is not always a reflection of the abundance of its transcript in the cell. Instead, folding and assembly have been considered as major bottlenecks in antibody production. Consequently, the engineering of mammalian cells as artificial factories has often tried to remove folding and assembly bottlenecks, i.e. by upregulating discrete steps in the process, as PDI and BiP. However these discrete approaches have not been particularly successful. Protein 
folding and assembly can be considered as a chain of potential bottlenecks, therefore it is not surprising that removal of a single bottleneck will only marginally alleviate constrains imposed in the system -reviewed by [40].

A more comprehensive approach recently undertaken to improve MAb production in artificial mammalian systems relies in a better understanding of plasma cell differentiation. Plasma cells are natural antibody factories: 


1
2
3
4
5
6
7
8
9
10
11
12
13
14
15
16
17
18
19
20
21
22
23
24
25
26
27
28
29
30
31
32
33
34
35
36
37
38
39
40
41
42
43
40
45
49
50
51
52
53
55
50

A

B

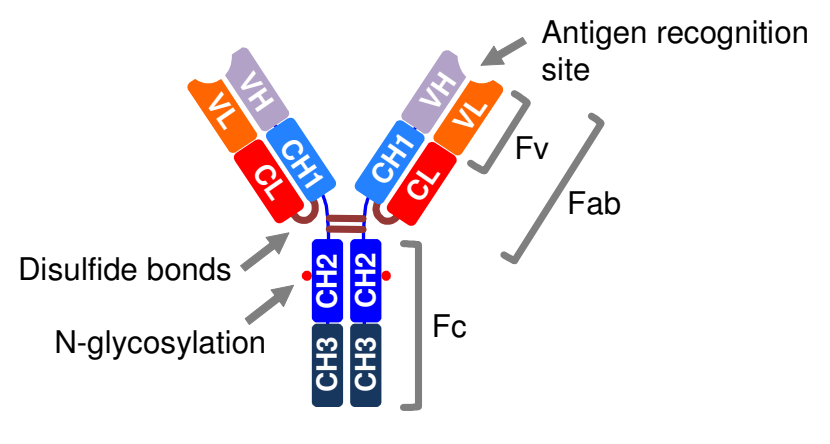

C

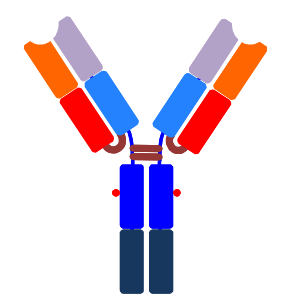

Full-length MAb

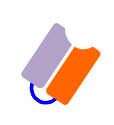

scFv $\quad$ VHH

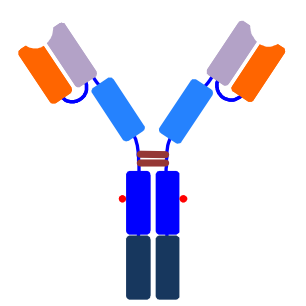

scFv-Fc

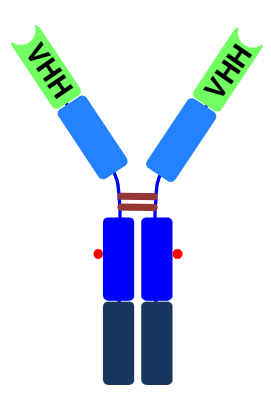




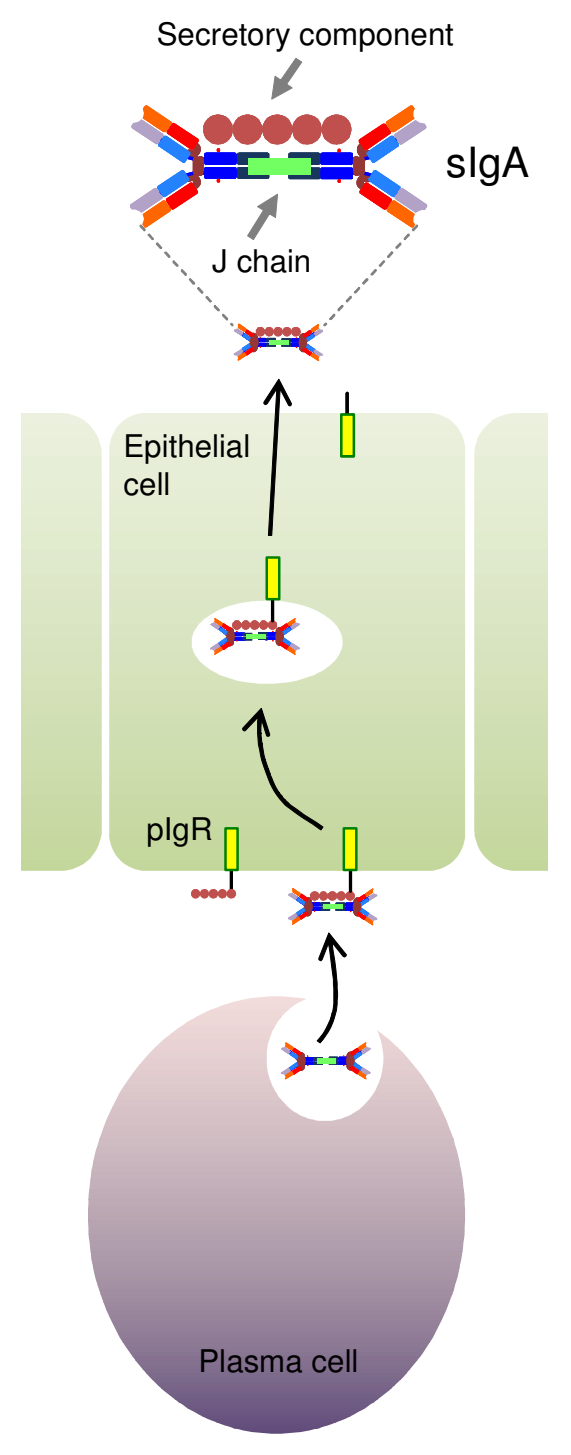

Wiley-VCH 


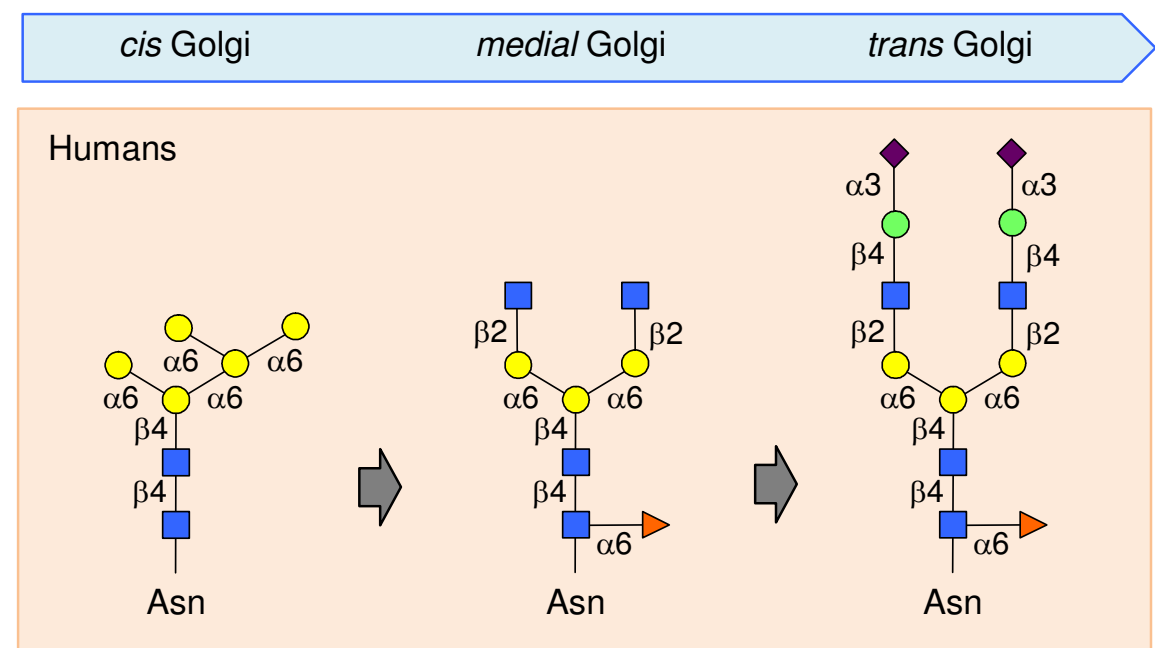

\section{Plants}

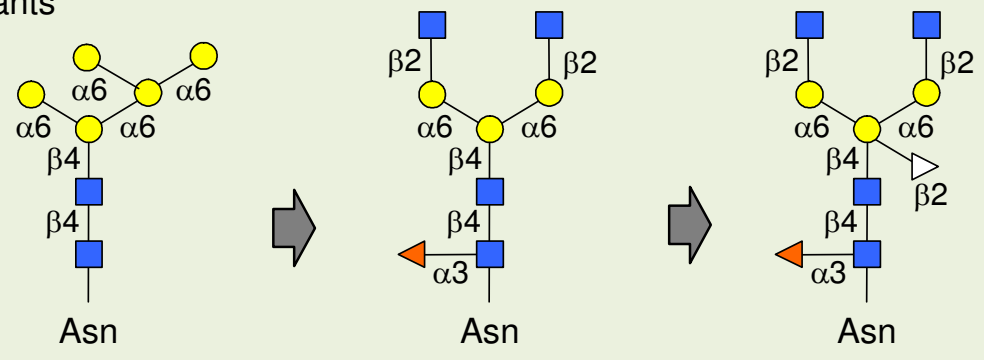

N-Acetylglucosamine

$\triangleright$ Fucose

$\bigcirc$ Galactose

Mannose

$\triangleright$ Xylose

$\checkmark$ Sialic acid 

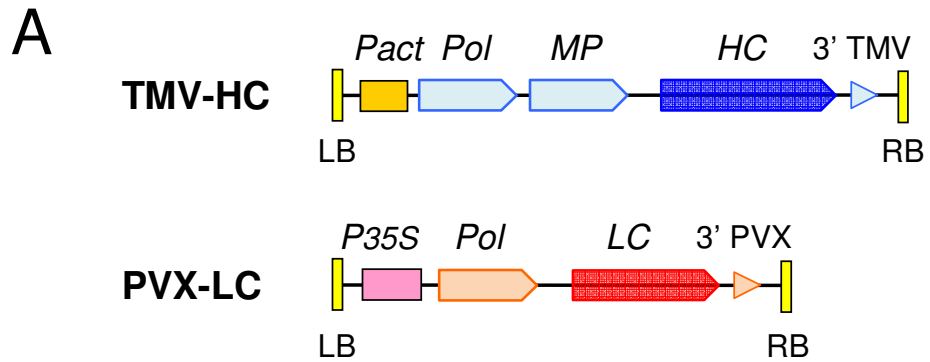

B

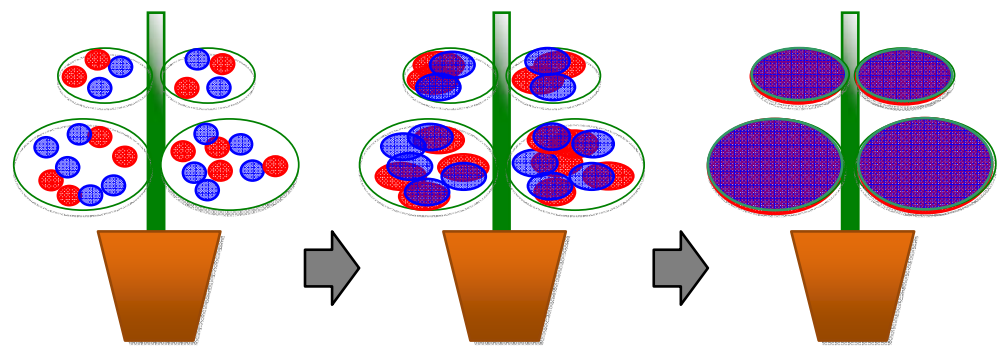

